\title{
Influence of impurities on the absorption spectrum of thin $\mathrm{Cs}_{4} \mathrm{Pbl}_{6}$ films
}

\author{
O.N.Yunakova, V.K.Miloslavskii, E.N.Kovalenko", V.V.Kovalenko \\ V.Kharkiv National University, 4 Svobody Sq., 61022 Kharkiv, Ukraine \\ *Kharkiv National University of Radioelectronics, \\ 14 Lenin Ave., 61166 Kharkiv, Ukraine
}

\section{Received March 27, 2014}

The absorption spectrum of the solid solutions $\left(\mathrm{Cs}_{1-x} \mathrm{M}_{x}\right)_{4} \mathrm{Pbl}_{6}(\mathrm{M}=\mathrm{Rb}, \mathrm{K}) \quad 0 \leq x \leq 1$ is studied in the spectral range $2-6 \mathrm{eV}$ at $T=90 \mathrm{~K}$. The formation of solid solutions $\left(\mathrm{Cs}_{1-x} \mathrm{Rb}_{x}\right)_{4} \mathrm{Pbl}_{6}$ in all range of concentrations, but $\left(\mathrm{Cs}_{1-x} \mathrm{~K}_{x}\right)_{4} \mathrm{Pbl}_{6}$ in the range $0 \leq x \leq 0.9$ is established, the compound $\mathrm{K}_{4} \mathrm{Pbl}_{6}$ is unstable. Linear concentration of long-wavelength exciton band parameters in the $\left(\mathrm{Cs}_{1-x} \mathrm{M}_{x}\right)_{4} \mathrm{Pbl}_{6}$ indicates the localization of excitons in $\mathrm{Pbl}_{6}{ }^{4-}$ structural elements of the compounds crystal lattice.

Исследован спектр поглощения твердых растворов $\left(\mathrm{Cs}_{1-x} \mathrm{M}_{x}\right)_{4} \mathrm{Pbl}_{6}(\mathrm{M}=\mathrm{Rb}, \mathrm{K}) 0 \leq x \leq 1$ в спектральном интервале $2-6$ эВ при $T=90 \mathrm{~K}$. Установлено образование твердых растворов $\left(\mathrm{Cs}_{1-x} \mathrm{Rb}_{x}\right)_{4} \mathrm{Pbl}_{6}$ во всем интервале концентраций $x$, а $\left(\mathrm{Cs}_{1-x} \mathrm{~K}_{x}\right)_{4} \mathrm{Pbl}_{6}-$ в интервале $0 \leq x \leq 0.9$, соединение $\mathrm{K}_{4} \mathrm{Pbl}_{6}$ неустойчиво. Линейный концентрационный ход параметров длинноволновой экситонной полосы в $\left(\mathrm{Cs}_{1-x} \mathrm{M}_{x}\right)_{4} \mathrm{Pbl}_{6}$ свидетельствует о локализации экситонов в $\mathrm{Pbl}_{6}^{4-}$ структурных элементах кристаллической решетки соединений.

Вплив домішок на спектр поглинання тонких плівок $\mathbf{C s}_{4} \mathrm{Pbl}_{6}$. О.Н. Юнакова, В.К. Милославський, Е.Н.Коваленко, В.В.Коваленко.

Досліджено спектр поглинання твердих розчинів $\left(\mathrm{Cs}_{1-x} \mathrm{M}_{x}\right)_{4} \mathrm{Pbl}_{6}(\mathrm{M}=\mathrm{Rb}, \mathrm{K}) 0 \leq x \leq 1$ у спектральному інтервалі $2-6$ еВ при $T=90 \mathrm{~K}$. Установлено утворення твердих розчинів $\left(\mathrm{Cs}_{1-x} \mathrm{Rb}_{x}\right)_{4} \mathrm{Pbl}_{6}$ в усьому інтервалі концентрацій $x$, а $\left(\mathrm{Cs}_{1-x} \mathrm{~K}_{x}\right)_{4} \mathrm{Pbl}_{6}-$ в інтервалі $0 \leq x \leq 0.9$, сполука $\hat{E}_{4} \mathrm{Pbl}_{6}$ нестійка. Лінійний концентраційний хід параметрів довгохвильової екситонної смуги у $\left(\mathrm{Cs}_{1-x} \mathrm{M}_{x}\right)_{4} \mathrm{Pbl}_{6}$ свідчить про локалізацію екситонів в $\mathrm{Pbl}_{6}{ }^{4-}$ структурних елементах кристалічної гратки сполук.

\section{Introduction}

The alkali metal halides $\mathrm{Ml}(\mathrm{M}=\mathrm{Cs}, \mathrm{Rb}$, K) form with $\mathrm{Pbl}_{2}$ two types of compounds $\mathrm{MPbl}_{3}$ and $\mathrm{M}_{4} \mathrm{Pbl}_{6}$, as evidenced by the study of their absorption spectra [1-4], and luminescence spectra [5, 6]. It is found that in systems $\mathrm{Ml}-\mathrm{Pbl}_{2}(\mathrm{M}=\mathrm{Cs}, \mathrm{Rb})$ the second compound $\mathrm{M}_{4} \mathrm{Pbl}_{6}$ is more stable and even two-phase film (doped $\mathrm{MPbl}_{3}$ ) annealing at high temperature pass into $\mathrm{M}_{4} \mathrm{Pbl}_{6}[1-3]$. At the same time the compound $\mathrm{K}_{4} \mathrm{Pbl}_{6}$ is unstable and get monophasic thin films $\mathrm{K}_{4} \mathrm{Pbl}_{6}$ failed [4].
The compounds $\mathrm{MPbl}_{3}$ and $\mathrm{M}_{4} \mathrm{Pbl}_{6}$ crystallize in a perovskite-type structure, a structural element of the crystal lattice are octahedra $\mathrm{Pbl}_{6}{ }^{4-}[7,8]$. Among the compounds $\mathrm{M}_{4} \mathrm{Pbl}_{6}$ crystal structure was studied only in $\mathrm{Cs}_{4} \mathrm{Pbl}_{6}[9,10] . \mathrm{Cs}_{4} \mathrm{Pbl}_{6}$ has a hexagonal lattice with unit cell parameters $a=14.52 \AA$, $a=18.31 \AA$ and the number of molecules to $z=6$.

The absorption spectra of $\mathrm{Cs}_{4} \mathrm{Pbl}_{6}$ and $\mathrm{Rb}_{4} \mathrm{Pbl}_{6}$ thin films are similar in spectrum structure and position of the absorption bands. Moreover, they are similar to the spectra of $\mathrm{Pb}^{2+}$ impurity bands in alkali hal- 
ide crystals and, as impurity bands, are interpreted based on the electronic transitions in the octahedra $\left(\mathrm{Pbl}_{6}\right)^{4-}[1-3]$. From the analysis of the spectra set localization of exciton states in the sublattice containing by ions $\mathrm{Pb}^{2+}$, surrounded by ions $\mathrm{I}^{-}$.

In this paper we investigate the absorption spectra of mixed films $\left(\mathrm{Cs}_{1-x} \mathrm{Rb}_{x}\right)_{4} \mathrm{Pbl}_{6}$ and $\left(\mathrm{Cs}_{1-x} \mathrm{~K}_{x}\right)_{4} \mathrm{Pbl}_{6}$ to determine the influence of impurities on the absorption and stability of the compounds $\mathrm{M}_{4} \mathrm{Pbl}_{6}(\mathrm{M}=\mathrm{Cs}, \mathrm{Rb}, \mathrm{K})$.

\section{Experimental}

The thin films $\left(\mathrm{Cs}_{1-x} \mathrm{Rb}_{x}\right)_{4} \mathrm{Pbl}_{6}$ and $\left(\mathrm{Cs}_{1-x} \mathrm{~K}_{x}\right)_{4} \mathrm{Pbl}_{6} 0 \leq x \leq 1$ were prepared by vacuum evaporation of the melt mixture of pure powders $\mathrm{Csl}$, $\mathrm{RbI}(\mathrm{KI})$ and $\mathrm{Pbl}_{2}$ stoichiometric composition and at a given concentration $x$ on quartz substrate heated to $160^{\circ} \mathrm{C}$ with subsequent annealing for $2 \mathrm{~h}$ at the same temperature. This method was used previously for the preparation of thin films $\mathrm{Cs}_{4} \mathrm{Pbl}_{6}$ and $\mathrm{Rb}_{4} \mathrm{Pbl}_{6}[2,3]$.

The phase composition of the films was controlled by the absorption spectra measured at $T=90 \mathrm{~K}$. Such control is possible because of the significant differences in the spectral position of long-wavelength exciton bands in $\mathrm{MPbl}_{3}(2.97-3.03 \mathrm{eV}), \mathrm{M}_{4} \mathrm{Pbl}_{6}$ $(3.4 \mathrm{eV}), \mathrm{Pbl}_{2}(2.5 \mathrm{eV})$ and $\mathrm{Ml}(5.7-5.8 \mathrm{eV})$ $(\mathrm{M}=\mathrm{Cs}, \mathrm{Rb}, \mathrm{K})$.

Solid solutions $\left(\mathrm{Cs}_{1-x} \mathrm{Rb}_{x}\right)_{4} \mathrm{Pbl}_{6}$ formed in the all concentration range $0 \leq x \leq 1$, and thin films $\left(\mathrm{Cs}_{1-x} \mathrm{~K}_{x}\right)_{4} \mathrm{Pbl}_{6}$ we managed to get in the range $0 \leq x \leq 0.9$. The pure films $\mathrm{K}_{4} \mathrm{Pbl}_{6}$ without impurities $\mathrm{KPbl}_{3}$ could not be obtained.

Absorption spectra of thin films were measured on spectrophotometer SF-46 in the spectral range $2-6 \mathrm{eV}$ at $T=90 \mathrm{~K}$. The films thickness of $80-160 \mathrm{~nm}$ were used for measurements.

Parameters of long-wavelength excitonic bands (position $E_{m}$, half-width $\Gamma$ and $\varepsilon_{2 m}=$ $\varepsilon_{2}\left(E_{m}\right)$ - the value of the imaginary part of the dielectric constant in the band maximum) were determined, in accordance with [11], by approximating of the exciton band by a symmetric single-oscillator profile, which is a linear combination of Lorentz and Gaussian profile. The exciton band parameters $\left(E_{m}, \Gamma\right.$ and $\left.\varepsilon_{2 m}\right)$ were chosen to obtain the best fit of the calculated profile to the measured spectrum at the long-wavelength slope of the band.

\section{Results and dicussion}

The absorption spectrums of thin films $\left(\mathrm{Cs}_{1-x} \mathrm{Rb}_{x}\right)_{4} \mathrm{Pbl}_{6} 0 \leq x \leq 1$ (Fig. 1) are similar in structure and spectral position of the absorption bands. In the interval $0 \leq x \leq 0.9$ $\left(\mathrm{Cs}_{1-x} \mathrm{~K}_{x}\right)_{4} \mathrm{Pbl}_{6}$ absorption spectra are also similar (Fig. 1).

The absorption spectra of thin films $\left(\mathrm{Cs}_{1-x} \mathrm{Rb}_{x}\right)_{4} \mathrm{Pbl}_{6}$ and $\left(\mathrm{Cs}_{1-x} \mathrm{~K}_{x}\right)_{4} \mathrm{Pbl}_{6}$ have $A, C$ and $D$ exciton bands. Spectral position of the exciton bands for $\mathrm{Cs}_{4} \mathrm{Pbl}_{6}, \mathrm{Rb}_{4} \mathrm{Pbl}_{6}$ and $\left(\mathrm{Cs}_{0.1} \mathrm{~K}_{0.9}\right)_{4} \mathrm{Pbl}_{6}$ shown in Table. Since the spectra of the investigated solid solutions similar to those of single-phase films $\mathrm{Cs}_{4} \mathrm{Pbl}_{6}, \mathrm{Rb}_{4} \mathrm{Pbl}_{6}$, they, like spectra $\mathrm{Cs}_{4} \mathrm{Pbl}_{6}$, $\mathrm{Rb}_{4} \mathrm{Pbl}_{6}[1-3]$, can be interpreted on the basis of the electronic transitions in the octahedra $\left(\mathrm{Pbl}_{6}\right)^{4-}: A_{1}$ exciton band corresponds to the transition ${ }^{1} A_{1 g} \rightarrow{ }^{3} T_{1 u}, C$ bands corresponds to the transition ${ }^{1} A_{1 g} \rightarrow{ }^{1} T_{1 u}$.

Concentration dependence of the spectral position $E_{m}(x)$ and half-width $\Gamma(x)$ longwavelength exciton bands $A_{1}$ in $\left(\mathrm{Cs}_{1-x} \mathrm{Rb}_{x}\right)_{4} \mathrm{Pbl}_{6}$ are linear (Fig. 2), which confirms the localization of exciton states in the structural elements of the crystal lattice $\left(\mathrm{Pbl}_{6}\right)^{4-}$.

In the concentration dependence of the spectral position $A_{1}$ band in $\left(\mathrm{Cs}_{1-x} \mathrm{~K}_{x}\right)_{4} \mathrm{Pbl}_{6}$ observed deviation from linearity with increasing $x$ to higher frequencies (Fig. 2a), which could be associated with disordered of solid solution. The bend of $E_{m}(x)$ dependence, however to lower frequencies, is well known for the exciton bands in solid solutions of binary compounds and caused to small-scale fluctuations in disordered solid solutions. But in such solid solutions, the half-width $\Gamma(x)$ also increases with increas-

Table. The spectral position of the absorption bands, the exciton binding energy $R_{e x}$ and the band gap $E_{g}$ in the investigated compounds

\begin{tabular}{|c|c|c|c|c|c|c|c|c||}
\hline Compound & $E_{A 1}, \mathrm{eV}$ & $E_{A 2}, \mathrm{eV}$ & $E_{C 1}, \mathrm{eV}$ & $E_{C 2}, \mathrm{eV}$ & $E_{C 3}, \mathrm{eV}$ & $E_{D}, \mathrm{eV}$ & $R_{e x}, \mathrm{eV}$ & $E_{g}, \mathrm{eV}$ \\
\hline $\mathrm{Cs}_{4} \mathrm{Pbl}_{6}[2]$ & 3.41 & 3.522 & 4.19 & 4.36 & 4.73 & 5.2 & 0.149 & 3.56 \\
$\mathrm{Rb}_{4} \mathrm{Pbl}_{6}[3]$ & 3.41 & 3.512 & 4.1 & 4.43 & 4.73 & 5.28 & 0.133 & 3.543 \\
$\left(\mathrm{Cs}_{0.1} \mathrm{~K}_{0.9}\right)_{4} \mathrm{Pbl}_{6}$ & 3.43 & 3.54 & 4.16 & 4.49 & 4.77 & 5.17 & 0.147 & 3.577 \\
\hline
\end{tabular}




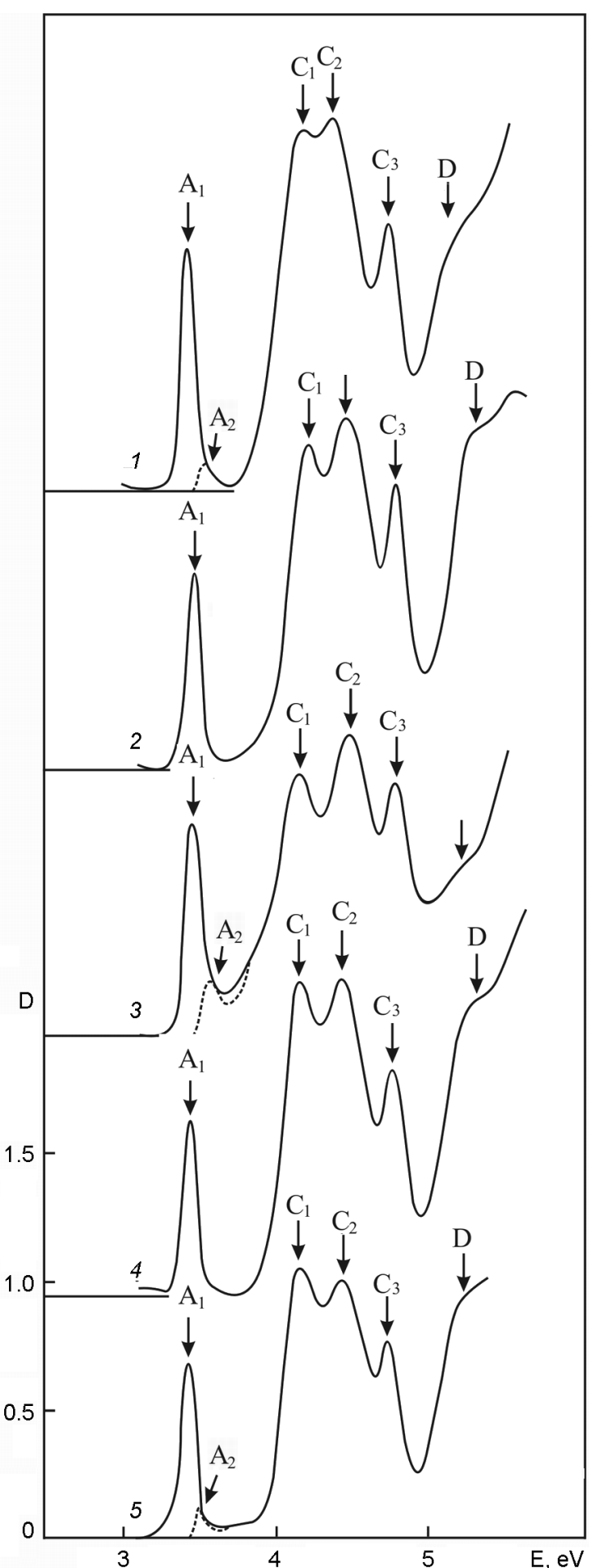

Fig. 1. Absorption spectra of thin films $\left(\mathrm{Cs}_{1-x} \mathrm{~K}_{x}\right)_{4} \mathrm{Pbl}_{6}(1,2,3)$ and $\left(\mathrm{Cs}_{1-x} \mathrm{Rb}_{x}\right)_{4} \mathrm{Pbl}_{6}(1$, $4,5) T=90 \mathrm{~K}$, dotted is absorption edge after separation of $A_{1}$ band by symmetric contour.

ing $x$, reaching a maximum at $x=0.5$. However, in $\left(\mathrm{Cs}_{1-x} \mathrm{~K}_{x}\right)_{4} \mathrm{Pbl}_{6}$ concentration course $\Gamma(x)$ is line (Fig. 2b), indicating that the localization of exciton states in the
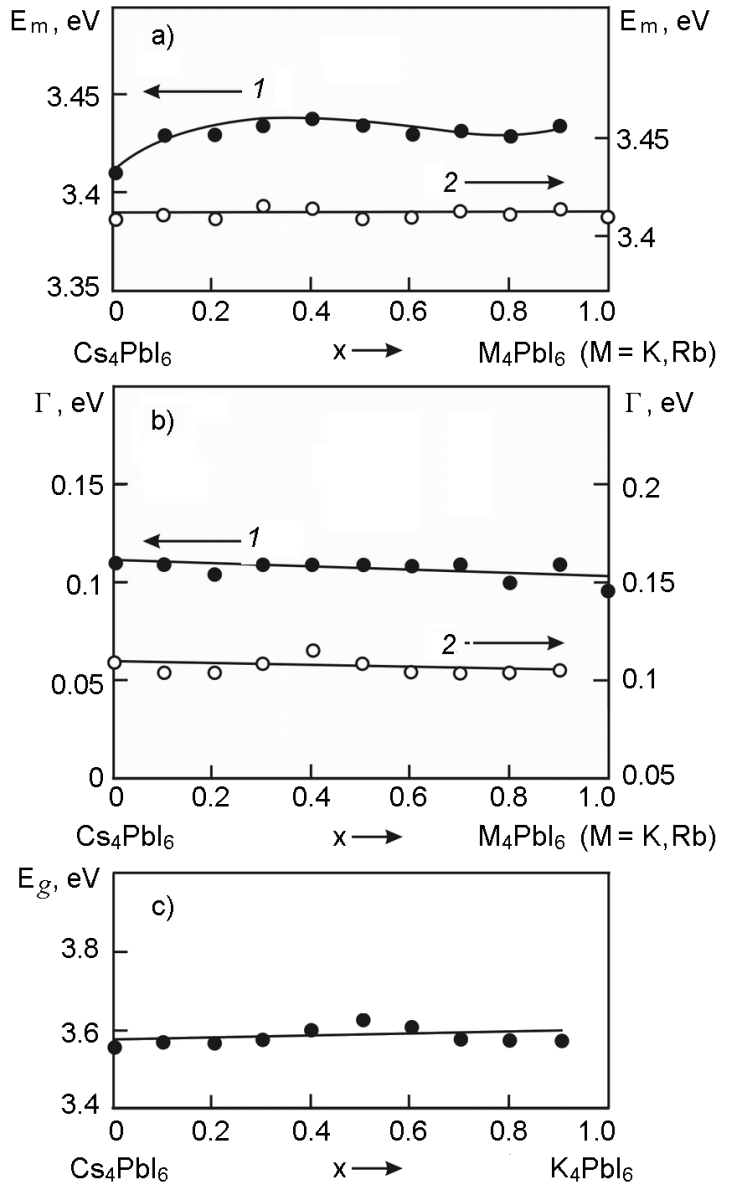

Fig. 2. Concentration dependences of the spectral position $E_{m}(x)$ (a) and half-width $\Gamma(x)$ (b) of long-wavelength exciton band $A_{1}$ at $T=90 \mathrm{~K} \quad$ in $\left(\mathrm{Cs}_{1-x} \mathrm{Rb}_{x}\right)_{4} \mathrm{Pbl}_{6} \quad$ (1) and $\left(\mathrm{Cs}_{1-x} \mathrm{~K}_{x}\right)_{4} \mathrm{Pbl}_{6}(2)$ and band gap $E_{g}(x)$ (c) in $\left(\mathrm{Cs}_{1-x} \mathrm{~K}_{x}\right)_{4} \mathrm{Pbl}_{6}$.

sublattice containing ions $\mathrm{Pb}^{2+}$. This conclusion is also supported by the linear concentration dependence of the band gap $E_{g}(x)$ (Fig. 2).

In $\mathrm{Cs}_{4} \mathrm{Pbl}_{6}$ the octahedra $\left(\mathrm{Pbl}_{6}\right)^{4-}$ are surrounded by ions $\mathrm{Cs}^{+}$[9]. With the substitution of ions $\mathrm{Cs}^{+}$(ionic radius $r=169 \mathrm{pm}$ [12]) by ions with significantly smaller radius $\mathrm{K}^{+}$( $r=133 \mathrm{pm}$ [12]) lattice deformation and thus the tension in environment by octahedra $\left(\mathrm{Pbl}_{6}\right)^{4-}$ arises in solid solutions $\left(\mathrm{Cs}_{1-x} \mathrm{~K}_{x}\right)_{4} \mathrm{Pbl}_{6}$, which apparently leads to the high-frequency shift of $A_{1}$ exciton band. The difference in the ionic radius of $\mathrm{Cs}^{+}$ $\left(r=169 \mathrm{pm}\right.$ [12]) and $\mathrm{Rb}^{+}(r=148 \mathrm{pm} \mathrm{[12])}$ is much smaller, so the substitution of $\mathrm{Cs}^{+}$ ions by ions $\mathrm{Rb}^{+}$in solid solutions $\left(\mathrm{Cs}_{1-x} \mathrm{Rb}_{x}\right)_{4} \mathrm{Pbl}_{6}$ makes no additional changes in the spectral position of $A_{1}$ band. 
As noted above, the compound $\mathrm{K}_{4} \mathrm{Pbl}_{6}$ without impurities $\mathrm{KPbl}_{3}$ us get failed. However, solid solutions $\left(\mathrm{Cs}_{1-x} \mathrm{~K}_{x}\right)_{4} \mathrm{Pbl}_{6}$ formed up to $x=0.9$, even a small admixture of $\mathrm{Cs}^{+}$stabilizes the compound. Assuming that the solid solution $\left(\mathrm{Cs}_{0.1} \mathrm{~K}_{0.9}\right)_{4} \mathrm{Pbl}_{6}$ closest to $\mathrm{K}_{4} \mathrm{Pbl}_{6}$, we investigated in more detail its spectrum. The spectral position of the exciton bands in $\left(\mathrm{Cs}_{0.1} \mathrm{~K}_{0.9}\right)_{4} \mathrm{Pbl}_{6}$ given in Table 1. After separation of the band $A_{1}$ by symmetric contour the shoulder $A_{2}$ observed in the long-wave side of the band $C_{1}$ at $3.54 \mathrm{eV}$ (Fig. 2a), we associate $A_{2}$ with the exciton in the state with principal quantum number $n=2$ ( $2 s$ exciton). Assuming that the bands $A_{1}$ and $A_{2}$ are exciton series with headband $A_{1}$, we estimated in their spectral position in the approximation of Wannier-Mott exciton the exciton binding energy $R_{e x}=4 / 3\left(E_{A 2}-E_{A 1}\right)=0.147 \mathrm{eV}$ and the band gap $E_{g}=E_{A 1}+R_{e x}=3.577 \mathrm{eV}$.

Absorption spectrum $\left(\mathrm{Cs}_{0.1} \mathrm{~K}_{0.9}\right)_{4} \mathrm{Pbl}_{6}$ was measured about the long-wavelength exciton bands $A_{1}$ in the temperature range 90$500 \mathrm{~K}$.

With increasing temperature, the band $A_{1}$ linearly shifted to the low-frequency region of the spectrum with $d E_{m} / d T=-2.36 \cdot 10^{-4} \mathrm{eV} / \mathrm{K}$ (Fig. 3). The order of magnitude of such a shift is typical for most ionic crystals, which include test compound. In ionic crystals the interaction of excitons with longitudinal optical (LO) phonons dominates and the largest temperature change of the exciton bands parameters occur at $\hbar \omega_{\mathrm{LO}} \leq k T$. $\hbar \omega_{\text {LO }}$ values we estimated from the known values $\hbar \omega_{\mathrm{LO}}=13.7 \mathrm{meV}$ in $\mathrm{Pbl}_{2}[13], \hbar \omega_{\mathrm{LO}}$ $=17.5 \mathrm{meV}$ in $\mathrm{KI}[14]$ and $\hbar \omega_{\mathrm{LO}}=11 \mathrm{meV}$ in Csl [15]. Given the molar composition in $\left(\mathrm{Cs}_{0.1} \mathrm{~K}_{0.9}\right)_{4} \mathrm{Pbl}_{6} \hbar \omega_{\mathrm{LO}} \sim 11.74 \mathrm{meV}$.

With increasing temperature, the halfwidth of the exciton band $A_{1}$ grows nonlinearly due to exciton-phonon interaction (EPI) (Fig. 3b). Contribution to the broadening of the exciton bands due to EPI for excitons of different dimension $d(d=1,2$, $3)$ is defined as [19]

$$
\Gamma(T) \approx\left[\frac{\pi D^{2}}{\gamma(d / 2)(2 \pi B)^{d / 2}}\right]^{\frac{2}{4-d}},
$$

where $\gamma(d / 2)$ is the gamma function, which depends on $d, B$ is width of the exciton band and $D^{2}=0.5 C^{2} \hbar \omega_{\mathrm{LO}} \operatorname{cth}\left(\hbar \omega_{\mathrm{LO}} / 2 k T\right)$, $C^{2} / 2$ is the lattice relaxation energy related to formation of excitons. When processing
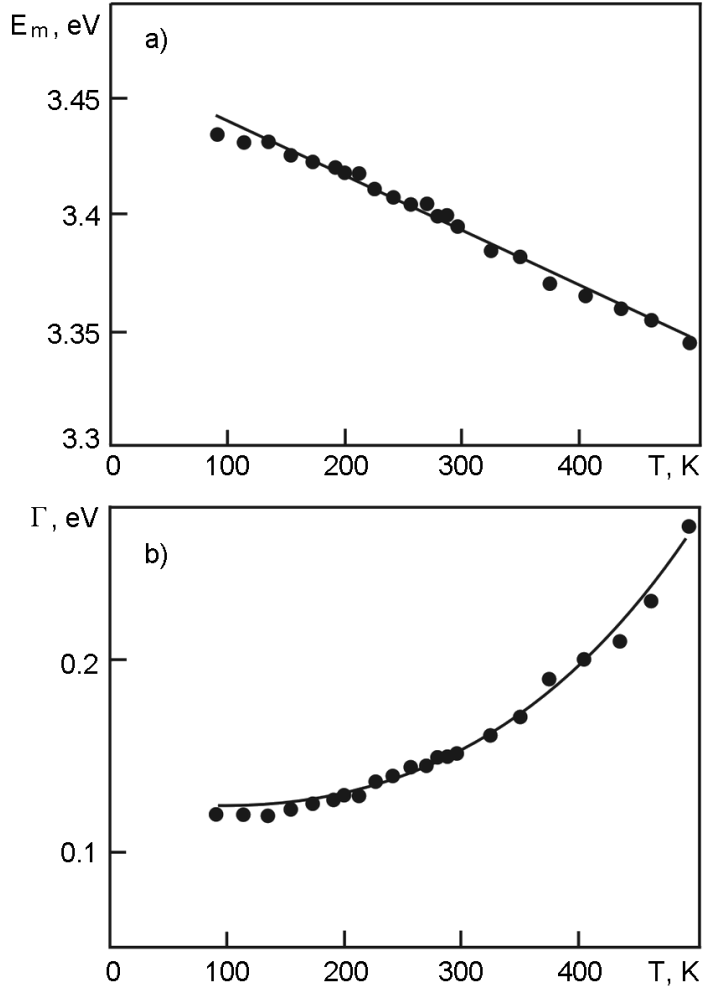

Fig. 3. Temperature dependence of the spectral position $E_{m}(T)$ (a) and half-width $\Gamma(x)(\mathrm{b})$ of long-wavelength exciton band $A_{1}$ in $\left(\mathrm{Cs}_{0.1} \mathrm{~K}_{0.9}\right)_{4} \mathrm{Pbl}_{6}$ : points is experiment, solid curves (b) is payment by Eq.(2), (3).

the experimental dependence of $\Gamma(T)$, we take into account the shape of the contour of the exciton band and contribute to $\Gamma$ of residual broadening $\Gamma(0)$ due to lattice defects. In the investigated temperature range form the exciton band $A_{1}$ is Gaussian. In the case of a Gaussian contour estimated halfwidth is given by

$$
\Gamma=\left[\Gamma^{2}(0)+\Gamma^{2}(T)\right]^{1 / 2},
$$

where $\Gamma(T)$ satisfies Eq.(1) with an unknown factor $A$, does not depend on $T$. Processing of experimental dependence $\Gamma(T)$ using Eq.(1) for different $d$ gives the best agreement between theory and experiment for $d=3$. In this case,

$$
\Gamma(T)=A \cdot c t h^{2}\left(\hbar \omega_{L O} / 2 k T\right)
$$

and the dependence of $\Gamma(T)$ in the coordinates of $\Gamma^{2}$ on $\operatorname{cth}^{4}\left(\hbar \omega_{\mathrm{LO}} / 2 k T\right)$ is linear. Processing of this dependence by the leastsquares method gives values of $\Gamma(0)=$ $0.12 \pm 0.0015$ and $A=(4.4 \pm 0.05) \cdot 10^{-4} \mathrm{eV}$. 
Calculated temperature dependence of $\Gamma(T)$ to Eq.(2), (3) with the found values $\Gamma(0)$ and $A$ is in good agreement with the experimental one (Fig. 2b).

Thus, as follows from the analysis of the temperature dependence of $\Gamma(T)$ excitons in $\left(\mathrm{Cs}_{0.1} \mathrm{~K}_{0.9}\right)_{4} \mathrm{Pbl}_{6}$ are three-dimensional character. Previously we installed 3D nature of the exciton excitations in $\mathrm{B} \mathrm{Cs}_{4} \mathrm{Pbl}_{6}$ [2] and $2 \mathrm{D}$ character in $\mathrm{Rb}_{4} \mathrm{Pbl}_{6}[3]$.

\section{Conclusions}

Found that solid solutions $\left(\mathrm{Cs}_{1-x} \mathrm{Rb}_{x}\right)_{4} \mathrm{Pbl}_{6}$ formed in all concentration range $0 \leq x \leq 1,\left(\mathrm{Cs}_{1-x} \mathrm{~K}_{x}\right)_{4} \mathrm{Pbl}_{6}$ formed in the range of $0 \leq x \leq 0.9$, the compound $\mathrm{K}_{4} \mathrm{Pbl}_{6}$ is unstable.

Linear concentration dependence of the spectral position $E_{m}(x)$ and half-width of $\Gamma(x)$ of long-wavelength exciton bands in solid solutions indicate the localization of exciton states in the sublattice containing ions $\mathrm{Pb}^{2+}$. The deviation of $E_{m}(x)$ in $\left(\mathrm{Cs}_{1-x} \mathrm{~K}_{x}\right)_{4} \mathrm{Pbl}_{6}$ from linear due, apparently, by local tensions in the environment of octahedra $\left(\mathrm{Pbl}_{6}\right)^{4-}$, which arising in the substitution of ions $\mathrm{Cs}^{+}$by significantly smaller radius ions $\mathrm{K}^{+}$.

From the analysis of the temperature dependence of the half-width $\Gamma(T)$ $\left(\mathrm{Cs}_{0.1} \mathrm{~K}_{0.9}\right)_{4} \mathrm{Pbl}_{6}$ installed three-dimensional character of exciton excitations.

\section{References}

1. S.Kondo, K.Amaya, T.Saito, J.Phys.:Condens. Matter., 15, 971 (2003)

2. O.N.Yunakova, V.K.Miloslavsky, E.N.Kovalenko, Optika i Spektroscopiya, 112, 90 (2012) [in Russian].

3. O.N.Yunakova, V.K.Miloslavsky, E.N.Kovalenko, E.V.Ksenofontova, Fizika Nizkikh Temperatur, 38, 1191 (2012) [in Russian].

4. O.N.Yunakova, V.K.Miloslavsky, E.N.Kovalenko, Functonal Materials, 20, 59 (2013).

5. S.V.Myagkota, Optika i Spektroscopiya, 87, 311 (1999) [in Russian].

6. V.Babin, P.Fabeni, M.Nikl et al., Phys.Stat. Sol.(b), 226, 419 (2001).

7. C.K.Moller, Nature, 182, 1436 (1958).

8. D.M.Trots, S.V.Myagkota, J.Phys.Chem.Sol., 69, 2520 (2008).

9. C.K.Moller, Mat.-Fus. Medd.K.Dan.Vidensk. Selsk., 32, 1 (1960).

10. B.D.Stepin, G.M.Serebrennikova, G.P.Chicherin et al., Zh. Neorg.Khim., 22, 3148 (1976)[in Russian].

11. O.N.Yunakova, V.K.Miloslavsky, E.N.Kovalenko, Optika $i$ Spektroscopiya, 104, 631 (2008) [in Russian].

12. I.T.Goronovskiy, Y.P.Nazarenko, E.F.Nekryach, Kratkiy Spravochnik po Khimii, Naukova Dumka, Kiev (1987) [in Russian].

13. G.Lukovsky, R.M.White, J.A. Benda et al., Sol.Stat.Com., 18, 811 (1976).

14. Eksitony, ed. by E.I.Rashba, Nauka, Moscow (1985) [in Russian].

15. F.Beerwerth, D.Frohlich, V.Leinweber, Phys. Stat.Sol. (b), 145, 195 (1988).

16. M.Schreiber, Y.Toyasawa, J.Phys.Soc. Japan, 51, 1528 (1982). 